\title{
Studies on Correlation between Yield and Yield Contributory Parameters and Quality of Okra [Abelmoschus esculentus (L.) Moench.] as Influenced by Zinc and Bio-Regulators
}

\author{
S.P. Singh* and R. Paliwal \\ Department of Horticulture, (SKN Agriculture University), S.K.N. College of Agriculture, \\ Jobner -303 329, Jaipur (Rajasthan), India \\ *Corresponding author
}

\section{A B S T R A C T}

\begin{tabular}{|l|}
\hline Ke y w o r d s \\
Okra, Correlation, \\
Contributory \\
Parameters, Bio- \\
regulators, Zinc, \\
Yield, Quality, etc. \\
\hline Article Info \\
\hline Accepted: \\
26 July 2017 \\
Available Online: \\
1 September 2017 \\
\hline
\end{tabular}

The present experiment was conducted to study the response of soil and foliar application of $\mathrm{Zn}$ and also of seed soaking along with foliar application of thiourea and kinetin on yield and yield contributory parameters and quality of okra. The increasing levels of zinc upto $5.0 \mathrm{~kg} \mathrm{ha}^{-}$ and $500 \mathrm{ppm}$ thiourea treatment through seed soaking + spray of $500 \mathrm{ppm}$ solution of thiourea at vegetative and flowering stages brought about substantial improvement in yield and yield attributing parameters along with quality attributes of okra fruits.

\section{Introduction}

Okra [Abelmoschus esculentus (L.) Moench] is known as Bhindi or lady's finger and grown throughout the world for its immature fruits. It occupies an important position among vegetables grown in India and abroad. In India, it covers over 0.40 million hectares area with annual production of 4.19 million tonnes (Anonymous, 2008). It is one of the most important green vegetable known for its nutritional, industrial and medicinal values. Okra contains $6.4 \%$ carbohydrate, $1.9 \%$ protein, $0.2 \%$ fat, $53 \mu \mathrm{g}$ beta-carotene, 0.07 $\mathrm{mg}$ thiamine, $0.1 \mathrm{mg}$ riboflavin, $13 \mathrm{mg}$ vitamin-C, $66 \mathrm{mg}$ calcium and $1.5 \mathrm{mg}$ iron /100g (Anonymous, 1980).
It is well documented that the growth and yield of okra crop plants are greatly influenced by a wide range of nutrients. Zinc is regarded as the third most important nutrient which limiting crop production after nitrogen and phosphorus (Takkar and Randhawa, 1980). According to Katyal and Rattan (1991) nearly half of the Indian soils and crops suffered from zinc deficiency of varying magnitude. Thiourea which is a kind of bio-regulator plays vital role in the physiology of plants through its stimulating action in various physiological activities. Thiourea has also been proved effective in mitigating drought in cluster bean and 
mothbean (Anonymous, 2004). Miller (1961) was the first to isolate kinetin from herring sperm DNA. Kinetin contains carbon, hydrogen, nitrogen and oxygen in ratio of $\mathrm{C}_{10}$ $\mathrm{H}_{9} \mathrm{~N}_{5} \mathrm{O}$. It plays role in initiation of cell division, delay of senescence, counteract apical dominance, induce flowering, cell enlargement, increase in protein synthesis and helps in breaking the dormancy too. Looking to the efficacy of these chemicals the present investigation entitled "Studies on correlation between yield and yield contributory parameters and quality of okra (Abelmoschus esculentus (L.) Moench.) as influenced by bio-regulators and zinc" was attempted.

\section{Materials and Methods}

A field experiment was conducted during 'kharif' seasons at Horticulture farm S.K.N. College of Agriculture, Jobner, Jaipur. The experiment was laid out in split-plot design with three replications. The experiment comprised of 28 treatment combinations. Four levels of zinc (Control, 2.5, 5.0 and $7.5 \mathrm{~kg} \mathrm{Zn}$ $\mathrm{ha}^{-1}$ ) were used as in main plot treatment during sowing and seven levels of thiourea and kinetin as foliar spray (at vegetative and flowering stage) and 500 ppm thiourea and 10 ppm kinetin through seed soaking and foliar spray were taken as sub plot treatment. The bio-regulators as pre-treatment were sprayed twice at 20 and 40 DAS. The experimental field was sandy-loam with slight alkaline in nature having $\mathrm{pH} 8.2$, poor in organic carbon $(0.17 \%)$, available nitrogen $\left(141.0 \mathrm{~kg} \mathrm{ha}^{-1}\right)$, phosphorus (17.0 kg ha $\mathrm{kg}^{-1}$ ) and medium in potassium (152.0 kg ha ${ }^{-1}$ ) contents. Manures and fertilizers applied in the crop as per recommended dose. Five plants were randomly tagged in each plot to record, the yield. The harvested fruits were analysed for various quality attributes.

The protein content and Crude fiber of fruit were calculated as per the method as suggested by A.O.A.C. (1960).Nitrogen, phosphorus and sulphur contents of fruit were analysed by the method as described by Subhiah and Asija (1956), Olsen's et al., (1954) and Tabatabai and Bremnes (1970), respectively. For zinc, plant samples were analyzed separately by atomic absorption spectrophotometer following the method as suggested by Lindsay and Norwell (1978).

\section{Results and Discussion}

\section{Response studies}

To describe relationship between fruit yield (Y) and applied zinc fertilizers (X), multiple regression studies were undertaken (Table 2) following the formulae:

$\mathrm{Y}=\mathrm{b}_{0}+\mathrm{b}_{1} \mathrm{x}+\mathrm{b}_{2} \mathrm{x}^{2}$

Describing the fruit yield (Y) as a function of main affect of zinc, which also showed a curvilinear trend expressed as a second degree polynomial. The predicted yield worked out from this quadratic function showed very high closeness to the observed data as evidenced from very high value of $\mathrm{R}^{2}\left(0.9986^{* *}\right)$.

Further, despite of very low degree of freedom for residual mean square (Residual d.f. $=1$ ), the partial regression coefficient b1 and $b 2$ of the second order function fitted to data were also found to be significant.

Data presented in table 2 revealed that the optimum dose of zinc for optimum yield was $4.899 \mathrm{~kg} \mathrm{Zn} \mathrm{ha}{ }^{-1}$ with corresponding optimum pooled fruit yield of $19096.65 \mathrm{~kg} \mathrm{ha}^{-1}$. Thus, the response to optimum level of $\mathrm{Zn}$ was found to be $6384.35 \mathrm{~kg}$ fruit yield $\mathrm{kg}^{-1}$ zinc applied.

\section{Correlation studies}

The data presented in table 3 shows that fruit yield of okra (Y) had very high degree of positive association with plant height $\left(\mathrm{X}_{1}\right)$, 
number of branches $\left(\mathrm{X}_{2}\right)$, number of leaves $\left(\mathrm{X}_{3}\right)$, chlorophyll content of leaf $\left(\mathrm{X}_{4}\right)$, fruit length $\left(\mathrm{X}_{5}\right)$, fruit diameter $\left(\mathrm{X}_{6}\right)$, number of fruit /plant $\left(\mathrm{X}_{7}\right)$ and fruit weight $\left(\mathrm{X}_{8}\right)$. Among the independent variables, plant height $\left(\mathrm{X}_{1}\right)$ was found to have very high positive correlation with number of branches (0.97), number of leaves (0.94), chlorophyll content (0.98), number of fruit /plant (0.99), fruit weight (0.73), fruit length (0.89), fruit diameter (0.95) and yield (0.99). Similarly, the other independent variables also had very high degree positive association with each other reflecting their synergistic influence. Thus, all the independent variable (growth and yield attributes) favourably influence fruit yield of okra.

The data regarding the effect of different levels of bio-regulators and zinc on quality attributes has been summarized and presented as pooled mean of two years (2004 and 2005). Application of $5.0 \mathrm{~kg} \mathrm{Zn} \mathrm{ha}{ }^{-1}$ significantly increased the concentration of nitrogen and zinc (Table 1), whereas, it decreased the fiber content and phosphorus content of okra over control.

\section{Effect of zinc and bio-regulators}

The application of zinc $5.0 \mathrm{~kg} \mathrm{ha}^{-1}$ increased zinc content (46.95 mg/100 gm) 43.18 and 14.49 per cent over control and $2.5 \mathrm{~kg}$ zinc ha ${ }^{1}$, protein content $(18.00 \%) 39.53$ and 24.65 per cent over control and $2.5 \mathrm{~kg}$ zinc ha ${ }^{-1}$, nitrogen content $(2.88 \%) 39.81$ and 24.68 per cent higher in fruit over control and $2.5 \mathrm{~kg} \mathrm{Zn}$ $\mathrm{ha}^{-1}$, and sulphur content of fruits $(0.663 \%)$ 6.25 and 3.11 percent higher over control and $2.5 \mathrm{~kg} \mathrm{Zn} \mathrm{ha}{ }^{-1}$ while phosphors content did not affect $(0.444 \%)$.

Crude fiber content (12.64\%) decreased over control and $2.5 \mathrm{~kg} \mathrm{Zn} \mathrm{ha}^{-1}$ by 14.77 and 6.58 per cent, respectively (Table 3 ). Increase in dry matter in okra fruit might be due to increased photosynthetic activity, which favourably influenced the synthesis of carbohydrate, protein and other metabolites and efficient partitioning into fruit.

However, slight reduction in phosphorus concentration owing to the application of zinc may be due to the antagonism between zinc and phosphorus.

Table.1 Fruit yield (Y) as a function of zinc $(X)$ fertilization $\left(Y=b_{0}+b_{1} x+b_{2} x^{2}\right)$

\begin{tabular}{clcccc}
\hline S. No. & \multicolumn{1}{c}{ Study parameters } & & $\mathbf{2 0 0 4}$ & $\mathbf{2 0 0 5}$ & Pooled \\
\hline 1 & Partial regression coefficients & & & & \\
& & $\mathrm{b}_{0}$ & 13228.4 & 12195.25 & 12712.3 \\
& & $\mathrm{~b}_{1}$ & $211.156^{* *}$ & $205.35^{* *}$ & $208.232^{* *}$ \\
& & $\mathrm{~b}_{2}$ & $-1.6184^{* *}$ & $-1.5628^{* *}$ & $-1.5904^{* *}$ \\
2. & Coefficient of & & & & \\
& (i) Determination & $\mathrm{R}^{2}$ & $0.9985^{* *}$ & $0.9988^{* *}$ & $0.9986^{* *}$ \\
& (ii) Multiple correlation & $\mathrm{R}$ & $0.9992^{* *}$ & $0.9994^{* *}$ & $0.9993^{* *}$ \\
3. & Maximum level of $\mathrm{Zn}$ & $\mathrm{Zn}_{\max }$ & 6.524 & 6.570 & 6.547 \\
4. & Fruit yield at $\mathrm{Zn}$ max & $\mathrm{Y}_{\max }$ & 20115.89 & 18940.93 & 19528.28 \\
5. & Response at $\mathrm{Zn}$ max & & 6887.49 & 6745.68 & 6815.98 \\
6. & Optimum level of $\mathrm{Zn}$ & $\mathrm{Zn}_{\mathrm{opt}}$ & 4.905 & 4.894 & 4.899 \\
7. & Fruit yield at $\mathrm{Zn}$ opt & & 19691.73 & 18502.44 & 19096.65 \\
8. & Response at $\mathrm{Zn}_{\mathrm{opt}}$ & & 6463.33 & 6307.19 & 6384.35 \\
\hline
\end{tabular}

** Significant at 1 per cent level of significance

Note: (i) Zinc levels, fruit yield, responses and the intercept are given in $\mathrm{kg} \mathrm{ha}^{-1}$.

(ii) The partial regression coefficients $\left(b_{1}\right.$ and $\left.b_{2}\right)$ are based on $10 \mathrm{~kg} \mathrm{Zn}$ equal to 1 unit. 
Table.2 Matrix showing correlation coefficient of yield contributory characters and yield

\begin{tabular}{|c|c|c|c|c|c|c|c|c|c|}
\hline Characters & $\begin{array}{c}\text { Plant } \\
\text { height }(\mathbf{c m})\end{array}$ & $\begin{array}{c}\text { No. of } \\
\text { branches } \\
\text { per plant }\end{array}$ & $\begin{array}{l}\text { No. of leaves } \\
\text { per plant }\end{array}$ & $\begin{array}{l}\text { No. fruits } \\
\text { per plant }\end{array}$ & $\begin{array}{c}\text { Fruit } \\
\text { weight } \\
\text { (g) }\end{array}$ & $\begin{array}{c}\text { Fruit } \\
\text { length } \\
\text { (cm) }\end{array}$ & $\begin{array}{c}\text { Fruit } \\
\text { diameter } \\
(\mathrm{cm})\end{array}$ & $\begin{array}{l}\text { Chlorophyll } \\
\text { content }(\%)\end{array}$ & $\begin{array}{c}\text { Yield per } \\
\text { hectare } \\
\text { (q) }\end{array}$ \\
\hline Plant height (cm) & 1.000 & $0.969 * *$ & $0.943 * *$ & $0.991 * *$ & $0.734 * *$ & $0.886 * *$ & $0.946 * *$ & $0.982 * *$ & $0.995 * *$ \\
\hline No. of branches per plant & & 1.000 & $0.954 * *$ & $0.969 * *$ & $0.617 * *$ & $0.961 * *$ & $0.967 * *$ & $0.965 * *$ & $0.958 * *$ \\
\hline No. of leaves per plant & & & 1.000 & $0.963 * *$ & $0.583 * *$ & $0.898 * *$ & $0.898 * *$ & $0.955 * *$ & $0.948 * *$ \\
\hline No. fruits per plant & & & & 1.000 & $0.674 * *$ & $0.897 * *$ & $0.941 * *$ & $0.993 * *$ & $0.993 * *$ \\
\hline Fruit weight (g) & & & & & 1.000 & $0.489 * *$ & $0.667 * *$ & $0.609 * *$ & $0.754 * *$ \\
\hline Fruit length (cm) & & & & & & 1.000 & $0.956^{* *}$ & $0.901 * *$ & $0.874 * *$ \\
\hline Fruit diameter (cm) & & & & & & & 1.000 & $0.930 * *$ & $0.940 * *$ \\
\hline Chlorophyll content (\%) & & & & & & & & 1.000 & $0.933 * *$ \\
\hline Yield per hectare $(q)$ & & & & & & & & & 1.000 \\
\hline
\end{tabular}

Table.3 Effect of bio-regulators and zinc on quality of okra (pooled data 2004 and 2005)

\begin{tabular}{|c|c|c|c|c|c|c|}
\hline Treatments & $\begin{array}{l}\text { Zinc content in } \\
\text { fruit }(\mathrm{mg} / 100 \mathrm{~g})\end{array}$ & $\begin{array}{l}\text { Protein content } \\
\text { In fruit }(\%)\end{array}$ & $\begin{array}{c}\text { Crude fiber } \\
(\%)\end{array}$ & $\begin{array}{c}\text { Nitrogen } \\
\text { content }(\%)\end{array}$ & $\begin{array}{l}\text { Phosphorus } \\
\text { content }(\%)\end{array}$ & $\begin{array}{c}\text { Sulphur } \\
\text { content }(\%)\end{array}$ \\
\hline \multicolumn{7}{|l|}{ Zinc $\left(\mathrm{ha}^{-1}\right)$} \\
\hline $\mathrm{Zn}_{0}=$ Control & 31.79 & 12.90 & 14.83 & 2.06 & 0.462 & 0.624 \\
\hline $\mathrm{Zn}_{1}=2.5 \mathrm{~kg}$ & 39.76 & 14.44 & 13.53 & 2.31 & 0.457 & 0.643 \\
\hline $\mathrm{Zn}_{2}=5.0 \mathrm{~kg}$ & 45.52 & 18.00 & 12.64 & 2.88 & 0.444 & 0.663 \\
\hline $\mathrm{Zn}_{3}=7.5 \mathrm{~kg}$ & 46.95 & 18.09 & 12.77 & 2.89 & 0.428 & 0.675 \\
\hline $\mathrm{SEm}+$ & 0.785 & 0.123 & 0.244 & 0.020 & 0.007 & 0.007 \\
\hline $\mathrm{CD}(\overline{\mathrm{p}}=0.05)$ & 2.420 & 0.379 & 0.753 & 0.061 & NS & NS \\
\hline \multicolumn{7}{|l|}{ Bio-regulators } \\
\hline $\mathrm{B}_{1}=$ Water soaking (control) & 39.36 & 13.03 & 14.35 & 2.09 & 0.438 & 0.631 \\
\hline $\mathrm{B}_{2}=500 \mathrm{ppm}$ thiourea seed soaking & 40.38 & 15.28 & 13.91 & 2.45 & 0.440 & 0.638 \\
\hline $\mathrm{B}_{3}=10 \mathrm{ppm}$ kinetin seed soaking & 40.16 & 14.63 & 14.28 & 2.34 & 0.439 & 0.633 \\
\hline $\mathrm{B}_{4}=500 \mathrm{ppm}$ thiourea foliar spray at 20 and 40 DAS & 42.03 & 17.25 & 12.77 & 2.76 & 0.453 & 0.662 \\
\hline $\mathrm{B}_{5}=10 \mathrm{ppm}$ kinetin foliar spray at 20 and 40 DAS & 41.49 & 16.37 & 13.56 & 2.62 & 0.452 & 0.645 \\
\hline $\begin{array}{l}\mathrm{B}_{6}=500 \mathrm{ppm} \text { thiourea seed soaking }+500 \mathrm{ppm} \\
\text { thiourea foliar spray at } 20 \text { and } 40 \text { DAS }\end{array}$ & 42.62 & 18.53 & 12.06 & 2.97 & 0.456 & 0.683 \\
\hline $\begin{array}{l}\mathrm{B}_{7}=10 \mathrm{ppm} \text { kinetin seed soaking }+10 \mathrm{ppm} \text { kinetin } \\
\text { foliar spray at } 20 \text { and } 40 \text { DAS }\end{array}$ & 41.00 & 15.91 & 13.20 & 2.55 & 0.455 & 0.668 \\
\hline SEm \pm & 0.809 & 0.141 & 0.308 & 0.022 & 0.007 & 0.009 \\
\hline C.D. $(\bar{p}=0.05)$ & NS & 0.392 & 0.863 & 0.063 & NS & 0.027 \\
\hline
\end{tabular}


It seems that higher zinc concentration created hindrance in absorption and translocation of phosphorus from root to the above ground parts. Similar results were also reported by Karelia (1990), Sharma and Lal (1990) and Choudhary et al., (1997).

The application of zinc in zinc deficient soil increased the availability of zinc in rhizosphere, thereby increasing the zinc concentration and its uptake by enhancing exchange capacity of roots, which helped in increased absorption of nitrogen, phosphorus, zinc and sulphur from the soil. Further, the beneficial effect of zinc in chlorophyll formation might have resulted in increased auxin concentration and its stimulatory effect on most of the physiological and metabolic processes together with more available nitrogen, augmented the production of photosynthates and their translocation to different parts including fruit of okra, ultimately increased the concentration of zinc, nitrogen, phosphorus and sulphur in the fruits. Similar, results were reported by Balyan et al., (1994) in cauliflower and Dube et al., (2003) in tomato.

Among all the treatments of bio-regulators (thiourea and kinetin), seed soaking and foliar sprays at vegetative and flowering stages recorded significantly higher quality parameters. The increasing levels of bioregulators brought substantial improvement in all quality attributes. The application of 500 ppm thiourea through seed soaking as well as foliar sprays at 20 and 60 DAS significantly increased zinc content $(42.62 \mathrm{mg} / 100 \mathrm{gm})$, protein content (18.53), nitrogen content (2.97 $\%$ ) and sulphur content $(0.683 \%)$ though, phosphorus content did not influence. Similarly, the crude fiber content was recorded minimum in fruit (12.06\%). Application of thiourea (seed soaking + foliar spray) resulted in better utilization of nitrogen and phosphorus in soil probably due to the fact that application of thiourea might have helped in improved metabolic process of plants and better growth and root development leading to greater absorption of nutrients from rhizosphere. Solanki (2002), while working at Bikaner also reported that thiourea being a sulphydryl compound significantly improved the root growth. This might be due to metabolic role of - $\mathrm{SH}$ group in root physiology and biochemistry. Application of thiourea creates better microbial population in soil which may be responsible to mobilize essential nutrients. This may also be a possible cause of higher nitrogen, phosphorus and sulphur concentration and their uptake by the crop in present study.

The fiber content of okra fruit decreased, might as a consequence of increase in dry matter accumulation in fruit owing to increased photosynthetic activity, which favourably influence the photosynthesis and synthesis of carbohydrate, protein and other metabolites and efficient partitioning into fruit.

The increase in nitrogen, phosphorus, sulphur and protein content in okra fruits due to foliar spray of thiourea has also been reported by Khafi (1991) in mustard. Similarly, the positive effect of seed soaking with $500 \mathrm{ppm}$ thiourea was also reported by Shekhawat (1998) in mustard. Application of kinetin significantly increased the nitrogen, phosphorus and sulphur and protein content in fruit and decrease fiber content in fruit over control. The increase in quality parameters under influence of kinetin in okra, may be due to delay in plant senescence. These results are in close conformity with those as observed by Thomas et al., (1992) who reported significant increase in protein content in mustard. Similar results have also been reported by Burman et al., (2003) in cluster bean and Yadav (2005) in barley. 


\section{References}

A.O.A.C., 1960. Official methods of analysis, $18^{\text {th }}$ ed. Association of official agriculture chemats 16, Washington, DC. 20044.

Anonymous, 1980. Nutritive value of Indian food, National Institute of Nutrition, ICMR, Hyderabad.

Anonymous, 2004. Report, Directorate of Wheat Research, Karnal.

Anonymous, 2008. Indian Horticulture database-2008, National Horticulture Board, Ministry of Agriculture, Government of India, Sector-18, Gurgaon, p. 5.

Balyan, D.S., Joginder Singh, V.K. Srivastava, and J.Singh, 1994. Nitrogen and $\mathrm{Zn}$ interactions in cauliflower. Crop Res, 8: 3, 537-542.

Burman, Uday, B.K., Garg, and S.Kathju, 2003. Influence of kinetin on photosynthesis, $\mathrm{N}$ metabolism and yield of clusterbean under moisture deficit conditions. Indian J. Pl. Physiol., 8 (3): 287-291.

Choudhary, N.R., A.K.Vyas, and A.K.Singh, 1997. Growth and nutrient uptake in wheat as influenced by nitrogen, phosphorus and zinc fertilization. Ann. Agril. Res. 18 (3): 365-366.

Dube, B.K., P.Sinha and C.Chatterjee, 2003. Effect of zinc on yield and quality of tomato. Indian J. Hort., 60 (1): 59-63.

Karelia, G.N., 1990. Response of wheat to phosphorus and zinc fertilization and their residual effect on bajra and jowar fodder and their availability in soil. Ph.D. Thesis. Gujarat Agricultural University, Campus: Sardarkrushinagar.

Karelia, G.N., 1990. Response of wheat to phosphorus and zinc fertilization and their residual effect on bajra and jowar fodder and their availability in soil. Ph.D. thesis, Gujarat Agricultural University, Campus
Sardarkrushinagar.

Katyal, J.C., and R.K. Rattan, 1991. Distribution of zinc in Indian soils. Fertiliser News, 38 (3): 15-26.

Khafi, H.R., 1991. Effect of nitrogen, phosphorus and foliar applied agro chemical on growth, yield and quality of mustard. Ph. D. thesis, Rajasthan Agricultural University, Bikaner.

Lindsay, W.L., and W.A. Norwell, 1978. Development of DTPA soil test for zinc, iron, magnesium and calcium. Soil Sci. Soc. Am. J., 42 (3): 421-428.

Miller, C.O., 1961. Kinetin and kinetin like compounds. Modern Methods of Plant Analysis. 6: 194-202.

Olsen, S.R., V.C. Cole, F.S. Watamable and L.A. Dean, 1954. Estimation of available phosphorus in soil by extraction with $\mathrm{NaHCO}_{3}$. Circular, United States Department of Agriculture, pp. 939.

Sharma, S.K., and F.Lal, 1990. Effect of zinc application at different levels of nitrogen and phosphorus on yield and nutrient uptake by wheat (Triticum aestivum L.) in vertisol. National Seminar on Recent Development in Soil Research held at Rajasthan College of Agriculture, Udaipur, Dec., 22-25, 1990, F-75 p. 89.

Shekhawat, B.S., 1998. Effect of levels and sources of fertilizer sulphur and thiourea application on growth, yield and quality of mustard in arid western Rajasthan. Ph. D. Thesis, Rajasthan Agricultural University, Bikaner.

Solanki, N.S., 2002. Effect of thiourea and demethyl sulphoxide on phosphorus use efficiency, dry matter partitioning and productivity of clusterbean [Cyamopsis tetragonoloba (L.) Taub.]. Ph. D. Thesis, Maharana Pratap University of Agriculture and Technology, Udaipur.

Subbiah, B. V., and G.C. Asija, 1956. A rapid procedure for the estimation of 
available nitrogen in soil. Cur. Sci., 25 (7): 259-260.

Tabatabai, M.A., and J.M. Bremner, 1970. A simple turbidimetric method of determining total sulphur in plant materials. Agron. J., 62: 805-806.

Takkar, P.N., and N.S. Randhawa, 1980. Zinc deficiency in Indian soils and plants. Seminar on zinc wastes and their utilization, 15-16 Oct. organised by Indian Lead Zinc information centre and the Fertiliser Association of India, New Delhi.
Thomas, J.C., De Armond, R.L. and Bohnert, H.J. 1992. Influence of $\mathrm{NaCl}$ on growth, proline and phosphoenol pyruvate carbodylase levels in membrane of the mumecrystallinum suspension cultures. Pl. Physiol., 98: 626-631.

Yadav, L.R., 2005. Effect of bio-regulators on productivity of wheat (Triticum aestivum L. emend. Fiori and Paol) varieties under normal and late sown conditions. Ph.D. Thesis, Rajasthan Agricultural University, Bikaner.

\section{How to cite this article:}

Singh, S.P. and Paliwal, R. 2017. Studies on Correlation between Yield and Yield Contributory Parameters and Quality of Okra [Abelmoschus esculentus (L.) Moench.] as Influenced by Zinc and Bio-Regulators. Int.J.Curr.Microbiol.App.Sci. 6(9): 2458-2464. doi: https://doi.org/10.20546/ijcmas.2017.609.303 